\title{
STRATEGIES FOR IMPROVING DAIRY MILK QUALITY CONDUCTED BY INDONESIAN PRIVATE COOPERATIVE
}

\author{
Malika Uyun Erma*, Wijaya Jemi Cahya Adi \\ Politeknik Negeri Jember, Indonesia \\ *E-mail: uyun@polije.ac.id
}

\begin{abstract}
Milk is the result of the livestock subsector which has great potential to be developed in Indonesia. Development of dairy agribusiness is expected to be able to meet domestic milk consumption needs. The purpose of this study is to determine strategies that can be used as an effort to improve the quality of fresh milk, especially production managed by cooperatives. The location of the study was in Galur Murni Dairy Farmer Cooperative (KPGM) which is located in Jember Regency, East Java Province. This research was quantitative descriptive research. The research design deployed was case study to study intensively or deeply from the research target group. The analytical method used consisted of SWOT analysis, which was used to determine alternative strategies of the quality of diary milk production at Galur Murni Cattle Breeder Cooperative. Based on the results of the SWOT analysis, it is known that the alternative strategy that gets the highest weight is Strength Opportunity (SO) of 7.6. The strategies referred to in SO include quality control, increasing the number of experts (recruitment of experts), conducting counselling, and optimizing forage land as forage feed supplies.
\end{abstract}

\section{KEY WORDS}

Strategies, quality, dairy milk, food resilience.

Agribusiness development of dairy milk can be conducted in various ways. Cooperative repositioning is one of the ways in dairy agribusiness development. The existence of cooperatives is expected to be able to prosper its members and can create cooperative entrepreneurs. According to Soejono $(1997 ; 177)$ the entrepreneurs should be born from a group of cooperative people, that are, people who understand, live the true nature and principles of cooperatives and try to develop consistently.

Galur Murni Dairy Farmer Cooperative is one of private cooperative in Indonesia that produces fresh milk and dairy products in Jember Regency, East Java, Indonesia. Its brand is "Best Cow". This cooperative is used as a forum for several dairy farmers in Jember Regency to learn and develop their businesses. Based on Java Pos Radar Jember July 19 2016, the number of cooperative members who have joined is forty seven (cattle breeders having 275 cattles).

The market share of Galur Murni Dairy Farmer Cooperative currently prefers the local market rather than establishing a contract with a milk factory. The problem is that there is no organization that experiences no change, meaning that the change is certain to occur, especially related to the target market intended by an organization/company. Galur Murni Dairy Farmer Cooperative needs to prepare itself to develop a strategy to increase the target market (bargaining position), where its dairy product has only competed at the regional level and is possible to compete at the national levels or even the multinational levels.

Improving the quality of products (fresh milk) is the most important thing in marketing, in this case milk which is a product of Galur Murni Dairy Farmer Cooperative. According to Kotler (2000: 748 ) product quality is a feature, namely the characteristics complementing the function of a product and can be in the form of capital or physical structure of a product that is better than other similar products. The product quality in this study is focused on the consumer's side. This is in line with the definition of quality proposed by Gaspersz (2008) that quality is anything that is able to meet customer's desires or needs (meeting the needs 
of customers). Quality is even often regarded as a parameter of customer's satisfaction. Quality that refers to customer's satisfaction can later be used as an effort to change towards continuous improvement even as an effort to strengthen bargaining position. When a product has a good bargaining position, then an area can meet its population's needs for the product or can be said to have food resilience. Food resilience is the ability of a nation to ensure that all of its inhabitants obtain adequate, qualified, and safe food and things that are based on optimizing utilization and local resources (Soekartawi; 2008).

The purpose of this study is to determine strategies that can be used as efforts to improve the quality of fresh milk, especially production managed by cooperatives.

\section{METHODS OF RESEARCH}

This research is a quantitative descriptive research. According to Silalahi (2010: 28), quantitative descriptive presents further data from observations, such as investigations and measure the magnitude or distribution of these traits among certain group members.

The sampling technique deployed in this study was purposive sampling. According to Silalahi (2010: 272), purposive sample selection, sometimes referred to as judgment sampling, is choosng the best possible subject to provide information needed. In this study, the selected informant was Galur Murni Dairy Farmer Cooperative. Respondents in this study were leader and manager of Galur Murni Dairy Farmer Cooperative, breeders who become members of the cooperative, consumers of the dairy milk product produces by the cooperative, and expert respondents from related agencies.

SWOT analysis was used to obtain alternatives of strategies that will be recommended to the company (cooperative). The stages of the SWOT analysis were:

Data Collection Phase. Data collection was done by analyzing and identifying the company's internal and external environments, and was continued with the evaluation process of the company's internal and external factors using IFAS and EFAS matrices.

Analysis Phase. After the data collection phase, the next stage was the analysis phase, which utilizes all information from the data collection stage in quantitative model. The analytical models used in this study were the IE matrix and SWOT matrix.

According to Rangkuti (2014), the IE matrix has nine cell strategies, which can be grouped into three main strategies, namely: (a) Growth strategy is the growth of the company itself or diversification efforts; (b) Stability strategy is a strategy that is implemented without changing the direction of the strategy; (c) Retrenchment strategy is an effort to minimize or reduce the efforts made by the company. Furthermore, the SWOT matrix is a matrix that clearly illustrates how the external opportunities and threats faced by the company can be solved by the strengths and weaknesses of the company. This matrix produces four sets of possible alternative strategies.

\section{RESULTS AND DISCUSSION}

From in-depth interviews with expert respondents (the leader of Galur Murni Dairy Farmer Cooperative, breeders who become member of the cooperative, consumers, and experts from related agencies (Dinas Ketahanan Pangan and Peternakan Kab. Jember), it was obtained data which were categorized as strength, weaknesses, opportunities, and threats that affect the quality of dairy milk, especially in Jember Regency.

The strength possessed by the Galur Murni Dairy Farmers Cooperative in improving the quality of fresh milk is that it has several experienced experts in the field of dairy farming. These experts can direct farmers under the auspices of Galur Murni Dairy Farmer Cooperative to carry out dairy farming so that dairy farmers have a standard operating procedure in dairy farming. The farming starts from lust and mating time management, calf birth management, calf treatment management, feeding guidelines, water, cage hygiene, dairy cow hoof trimming, prevention of mastitis, heat stress management, management of storage of hazardous chemicals, etc. Correct dairy farming is the main thing that makes high quality fresh milk. 
Another strength possessed by Galur Murni Dairy Farmer Cooperative is that it has an SOP in collecting fresh milk, has tools and equipment to control the quality of fresh milk and establishes cooperation with IPS. All fresh milk produced by its members' dairy farmings is centered in Sumberbaru Subdistrict before being sent to IPS. At that place, all milk is tested for its $\mathrm{pH}$, bacteria and density to specify the low and high quality milk. Furthermore, fresh milk is accommodated in the cooling ice for a certain period of time. In the delivery of fresh milk, special treatment must also be given, aside from being transported using a cooling box, the delivery time must not exceed 6 hours. Establishing cooperation with IPS can have a positive impact on cooperatives, because basically IPS only receives high quality fresh milk. With this, quality control in Galur Murni Dairy Farmer Cooperative will always be maintained. The strength factors possessed by the Galur Murni Dairy Farmer Cooperative are summarized in Table 1 below.

Table 1 - Strength Factors in Galur Murni Dairy Farmer Cooperative

\begin{tabular}{|c|c|c|c|c|}
\hline No & Strength & Weight & Rate & Score \\
\hline 1 & Cooperative has experienced experts & 0,10 & 3 & 0,3 \\
\hline 2 & Cooperative has an SOP in collecting fresh milk & 0,2 & 4 & 0,8 \\
\hline 3 & Cooperative has standardized tools and equipment & 0,2 & 4 & 0,8 \\
\hline 4 & $\begin{array}{l}\text { Breeders who become member in Galur Murni Dairy Farmer Cooperative } \\
\text { have an SOP in dairy farming technique }\end{array}$ & 0,2 & 4 & 0,8 \\
\hline 5 & Galur Murni Dairy Farmer Cooperative cooperates with the milk receiving installation & 0,3 & 4 & 1,2 \\
\hline & Sub Total & 1,0 & & 3,9 \\
\hline
\end{tabular}

Source: Primary Data.

In Table 1, it can be explained that the weight of cooperation with IPS is the highest when compared to other strength factors, which is equal to 0.3 . Then the rate in collaboration with IPS is also at level 4, which means it is very influential. This indicates that establishing cooperation with IPS can be used as the spearhead in terms of quality control. Thus, all elements in the KPGM become increasingly motivated to be better, especially in the quality of fresh milk produced.

This is in accordance with the statement of marketing expert Don Peppers and Martha Rogers in Kotler (2009: 134) that the only value that can be created in a company is the value that comes from the customer - that is all the values that you have now and the value that you will have in the future. A business is called successful if you succeed in getting, maintaining, and growing customers. The customer is the only reason that the company builds a factory, hires employees, schedules meetings, creates workflows, or engages in any business activity, in the sense that without customers, a business will not work well.

The weaknesses possessed are the infrastructure problems owned by KPGM and the dairy farmers and the tools and equipment used to milk fresh milk. The infrastructure is in the form of buildings for storing fresh milk that are not owned by Galur Murni Dairy Farmer Cooperative and standard cowsheds that have not been owned by the dairy farmers. These things are influential for the quality of fresh milk produced. Fresh milk is very sensitive to free air, so if it is slightly contaminated with pungent aroma, the taste and aroma of fresh milk will change and it can reduce the quality of fresh milk. Therefore in Table 1, the weight for infrastructure each gets a value of 0.3 and the rate gets a value of 3 , which means it affects the production of high quality fresh milk. Then, the weight of the breeders' milking tools and equipment is 0,1 which means that it is less important but has an effect on the quantity and quality of milk produced. There were several breeders who had more than 15 cows and they used simple tools and methods in milking. However, the quantity and quality of the fresh milk produced is in accordance with the standard. It turns out that the farmer have nearly 20 years of experience in the dairy business, thus, they have mastered the technique of milking cows.

Another weakness is the lack of supervision to farmers. This is very important for the quality control of fresh milk produced. Even though they have an SOP in dairy farming, without any supervision, the farmers will implement the old method. Based on the statement from the manager of Galur Murni Dairy Farmer Cooperative, some of the fresh milk sent does not meet the quality standards and needs to be returned. Therefore, supervision is very 
important for dairy farmers in operating the dairy farming SOP. The weakness factors are summarized in Table 2 below.

Table 2 - Factors of Weakness in Galur Murni Dairy Farmer Cooperative

\begin{tabular}{lllll}
\hline No & Weakness & Weight & Rate & Score \\
\hline 1 & The infrastructure owned by the cooperative has not been standardized & 0,3 & 3 & 0,9 \\
2 & Dairy cow breeders' tools and equipment are still simple & 0,1 & 4 & 0,4 \\
3 & Lack of supervision to farmers & 0,3 & 4 & 1,2 \\
4 & The infrastructure owned by dairy farmers has not been standardized & 0,3 & 3 & 0,9 \\
\hline & Sub Total & 1,0 & & 3,4 \\
\hline
\end{tabular}

Source: Primary Data.

The opportunity that Galur Murni Dairy Farmers Cooperative has in producing quality fresh milk is that there is still a lot of land for animal feed. Because most people in Jember Regency are farmers, there are many forage alternatives that can be utilized by dairy farmers. Based on a statement from the Head of the Livestock Division of Jember Regency, the price of dairy cattle in Jember is cheaper compared to that of other regions. Therefore, these opportunities need to be developed into a strategy so that it becomes useful for Galur Murni Dairy Farmer Cooperative in increasing the quality of fresh milk.

Table 3 - Opportunity Factors in Galur Murni Dairy Farmers Cooperative

\begin{tabular}{|c|c|c|c|c|}
\hline No & Opportunity & Weight & Rating & Score \\
\hline 1 & The forage area that can be utilized for dairy cattle is quite extensive & 0,3 & 3 & 0,9 \\
\hline 2 & The price of feed is relatively cheap & 0,3 & 4 & 1,2 \\
\hline 3 & Other forage alternatives for dairy cattle are available & 0,4 & 4 & 1,6 \\
\hline & Sub Total & 1 & & 3,7 \\
\hline
\end{tabular}

Source: Primary Data.

The threats possessed by Galur Murni Dairy Farmer Cooperative are a disease that often attacks dairy cows and lack of water availability. KPGM needs to take into account the threats so that the threats do not disturb the production of high quality fresh milk.

Table 4 - Threat Factors in Galur Murni Dairy Farmer Cooperative

\begin{tabular}{lllll}
\hline No & Threat & Weight & Rating & Score \\
2 & Disease in dairy cows & 0,5 & 2 & 1 \\
2 & 0,5 & 1 & 2 \\
\hline & Water availability & 1,0 & & 2 \\
\hline
\end{tabular}

Source: Primary Data.

Table 5 - SWOT Analysis Matrix

\begin{tabular}{|c|c|c|}
\hline $\mathrm{n} / \mathrm{n}$ & $\begin{array}{l}\text { Strength (S) } \\
\text { Galur Murni Dairy Farmer Cooperative has } \\
\text { experienced experts } \\
\text { The cooperative has an SOP in collecting fresh } \\
\text { milk. } \\
\text { Cooperative has standardized tools and } \\
\text { equipment. } \\
\text { Breeders who become member in Galur Murni } \\
\text { Dairy Cooperative have an SOP in the dairy } \\
\text { farming technique } \\
\text { The cooperative cooperates with the milk } \\
\text { receiving installation }\end{array}$ & $\begin{array}{l}\text { Weakness }(\mathrm{W}) \\
\text { The infrastructure owned by the } \\
\text { cooperative has not been } \\
\text { standardized yet. } \\
\text { Dairy cow breeders' tools and } \\
\text { equipment are still simple. } \\
\text { There is lack of supervision to } \\
\text { farmers. } \\
\text { The infrastructure owned by } \\
\text { dairy farmers has not been } \\
\text { standardized. }\end{array}$ \\
\hline $\begin{array}{l}\text { Opportunity }(\mathrm{O}) \\
\text { The vast area of forage that can be utilized for dairy cattle } \\
\text { is quite extensive } \\
\text { The price of feed is relatively cheap } \\
\text { Other forage alternatives for dairy cattle are available. }\end{array}$ & $\begin{array}{l}\text { Strategy (SO) } \\
7,6\end{array}$ & $\begin{array}{l}\text { Strategy (OW) } \\
7,1\end{array}$ \\
\hline $\begin{array}{l}\text { Threat }(\mathrm{T}) \\
\text { Disease in dairy cows } \\
\text { Water availability }\end{array}$ & $\begin{array}{l}\text { Strategy (ST) } \\
5,9\end{array}$ & $\begin{array}{l}\text { Strategy (WT) } \\
5,4\end{array}$ \\
\hline
\end{tabular}

Based on the results of the SWOT analysis conducted, the position of Galur Murni Dairy Farmer Cooperative is in the strength-opportunity strategy. Galur Murni Dairy Farmer 
Cooperative needs to optimize the strengths and opportunities in producing high quality fresh milk. Alternative strategies include counseling to dairy farmers intensively, controlling quality in terms of SOPs for dairy farming to SOPs for fresh milk collection, optimizing forage and forage waste, recruiting experts so that counseling and supervision to farmers can run well.

In summary, the results of the matrix formulation based on SO, WO, ST, and WT are weighted to determine the scale of priority. The alternative arrangements based on the priority sequence obtained from the SWOT matrix weighting are presented in Table 5 below.

Table 6 - SWOT Alternative Sequences

\begin{tabular}{lll}
\hline Priority & Stategy & Score \\
\hline III & SO & 7,6 \\
III & WO & 7,1 \\
IV & ST & 5,9 \\
\hline
\end{tabular}

Source: Primary Data.

Based on the alternative strategy sequence formed from the results of the SWOT analysis as seen in Table 5, it can be seen that the alternative strategy that gets the highest weight is Strength - Opportunity (SO) of 7.6. Thus, it can be interpreted as a strategy by using the power to make the most of opportunities. The strategies referred to in SO include quality control, increasing the number of experts (recruitment), conducting counseling, and optimizing forage land as forage feed supplies.

\section{CONCLUSION}

Based on the results of the discussion in the study, it can be concluded that the alternative strategy in the SWOT analysis which gets the highest weight is Strength (Opportunity) (Opportunity) (SO) of 7.6. Thus, it can be interpreted as a strategy by using the power to make the most of opportunities. The strategies referred to in SO include quality control, increasing the number of experts (recruitment of experts), conducting counselling, and optimizing forage land as forage feed supplies.

\section{REFERENCES}

1. Agustina, Titin. (2016). Outlook Komoditas Pertanian Subsektor Peternakan Susu. Pusat Data and Sistem Informasi Pertanian Sekretariat Jenderal Kementerian Pertanian.

2. Ariani, Dorothea Wahyu. (2002). Manajemen Kualitas: Pendekatan Sisi Kualitatif. Jakarta: Direktorat Jenderal Pendidikan Tinggi Departemen Pendidikan.

3. Gaspersz, Vincent. (2008). Total Quality Management (TQM). Jakarta: PT Gramedia.

4. Haming, Murfidin and Mahfud Nurnajamuddin. (2007). Manajemen Produksi Modern: Operasi Manufaktur and Jasa. Jakarta: PT Bumi Aksara.

5. Heizer, J. (2006). Operations Management (Manajemen Operasi). Salemba Empat.

6. Hidaya, A. (2009). Pengenalan Manajemen Mutu dalam Penerapan Jaminan Mutu Berlabelkan Tanda. Direktorat Jenderal Pengolahan and Pemasaran Hasil Pertanian.

7. Irawati, Dany Alifah dkk. (2017). Strategi Pengembangan Koperasi Peternak Galur Murni di Kabupaten Jember. Jurnal Aplikasi Bisnis and Manajemen Vol.3, No.1, Januari 2017.

8. Kotler, Philip. (2000). Manajemen Pemasaran. Edisi Milenium. Jakarta: Prehallindo.

9. Kotler, Philip. (2009). Manajemen Pemasaran Edisi 13. Jakarta: Erlangga.

10. Kusrini. (2009). Konsep and Aplikasi Sistem Pendukung Keputusan. Yogyakarta: Andi.

11. Oktaviani, Rsky. (2014). Analisis Kelayakan Finansial and Strategi Pengembangan Usaha Susu Sapi Perah Pada Koperasi Peternak Galur Murni Kecamatan Sumberbaru Kabupaten Jember. IImiah Pertanian, Juni 2014.

12. Rangkuti, Freddy. (2012). Analisis SWOT: Teknik Membedah Kasus. Jakarta: PT.

13. Silalahi, Ulber. (2010). Metode Penelitian Sosial. Bandung: PT.Refika Aditama.

14. Soedjono Ibnoe. (1997). Koperasi and Pembangunan Nasional. Jakarta: PIP-Dekopin.

15. Soekartawi. (2008). Mewujudkan Kemandirian Pangan. Koran Jakarta, 31 Oktober 2008. 